tendency to produce flares up to the time of central meridian passage. On May 18 , however, a major flare occurred from $10 \mathrm{~h} .18 \mathrm{~m}$. until about $13 \frac{1}{2} \mathrm{~h}$. U.T., and this was associated with a marked radio fade-out on long-distance radio communication.

\section{The Night Sky in June}

NEw moon occurs on June 4d. 16h. 40m. U.T., and full moon on June $19 \mathrm{~d}$. $12 \mathrm{~h}$. $36 \mathrm{~m}$. The following conjunctions with the moon take place: June 2d. 21h., Mercury $7^{\circ}$ S.; June 8d. 18h., Venus $1^{\circ}$ S.; June 13d. 07h., Saturn $4^{\circ}$ N. ; June 27d. 01h., Jupiter $4^{\circ} \mathrm{S}$. Mercury is a morning star during most of the month but is too close to the sun for favourable observation; on June 25 the planet is in superior conjunction and afterwards becomes an evening star, but sets too soon after the sun-forty minutes on June 30-to be observed. Venus, an evening star, sets at $23 \mathrm{~h} .20 \mathrm{~m} ., 23 \mathrm{~h} .05 \mathrm{~m}$. and $22 \mathrm{~h} .30 \mathrm{~m}$. on June 1 , 15 and 30, respectively, and is a conspicuous object in the western sky. The planet reaches its greatest elongation east on June 25, and the visible portion of the illuminated disk varies between 0.62 and 0.45 during the month. Mars is too close to the sun to be observed. Jupiter is a morning star, rising at $\mathrm{lhr}$. $45 \mathrm{~m}$., $0 \mathrm{~h}$. $55 \mathrm{~m}$. and $0 \mathrm{~h}$. on June 1,15 and 30 , respectively. Saturn, an evening star, sets at 1h. $30 \mathrm{~m} ., 0 \mathrm{~h} .35 \mathrm{~m}$, and $23 \mathrm{~h}$. $35 \mathrm{~m}$. at the beginning, middle and end of the month, respectively, and can be seen for a fow hours during the night between $\beta$ and $\eta$ Virginis. Occultations of stars brighter than magnitude 6 are as follows: June $23 \mathrm{~d}$. $02 \mathrm{~h} .43 \cdot 7 \mathrm{~m}$., $\gamma$ Capr. $(D)$; June 25d. 0lh. 11·3m., 96 Aqar. $(R)$. $D$ and $R$ refer to disappearance and reappearance, respectively, and observations from Greenwich are assumed. Summer solstice occurs on June 22d. $05 \mathrm{~h}$.

\section{Announcements}

H.R.H. The Duke of Glovcester will open the new laboratories of the Tin Research Institute at Fraser Road, Greenford, Middlesex, on May 31.

Througr the generosity of Mrs. Armstrong, widow of the late Dr. E. F. Armstrong (president of the Royal Society of Arts and chairman of the Council during 1943-45), and of his son Mr. Richard Armstrong, an endowment has been made for the provision of biennial memorial lectures, to be delivered to the Society on the subject of food. It is hoped that it will be possible to arrange for the first Armstrong memorial lecture to be delivered in the next session of meetings.

A COLLOQUIUM on the "Chemotherapy of Tuber. culosis", organized by the Medical Research Council of Ireland, will be held in Trinity College, Dublin, during July 10-13. Further details can be obtained from the honorary secretary of the colloquium, J. G. Belton, at the Laboratories of the Medical Research Council, Trinity College, Dublin.

A spectal discussion meeting of the Royal Anthropological Institute will be held on May 30 to consider "Physical Aspects of Race". The speakers will include Prof. J. B. S. Haldane, Dr. A. E. Mourant, Dr. J. C. Trevor and Prof. S. Zuckerman, who have recently been appointed members of an expert panel of the United Nations Educational, Scientific and Cultural Organization which is to meet in Paris during June 4-8 to consider this subject.

AN ophthalmic optical trade exhibition, organized by the Association of Wholesale and Manufacturing
Opticians (secretary : B. G. Arthur, 69 Cannon Street, London, E.C.4), will be held in the two large halls of the Royal Horticultural Society at Vincent Square, London, S.W.1, during July 16-20. About a hundred firms will be exhibiting their products. Prior to the exhibition, during July $10-13$, the British Optical Association is sponsoring an international ophthalmic optical congress at King's College, London.

THE fourth annual conference on the "Education of the Young Worker", organized by the Department of Education, University of Oxford, will be held at Manchester College, Oxford, during July 7-13. The aim of the conference is to bring together representatives of industry, education and administration to consider the facilities that already exist for the training of young people, what better use might be made of them, and what should be the ideal programme for the future. The programme can be obtained from the Director, University Department of Education, 15 Norham Gardens, Oxford.

A SERIES of Festival symposia, organized jointly by the Royal Society of Medicine and the British Medical Association, will be held during June at I Wimpole Street, London, W.1. The symposia will be open to all members of the medical profession, British and foreign. Some of the topics to be discussed are as follows : the peripheral nervous system (June 4, 2.15 p.m.) ; antibiotics (June 7, 2.15 p.m.) ; ophthalmology (June 11, 2.30 p.m.); the central nervous system (June 14, 2 p.m.); experimental endocrinology (June 20, 2.15 p.m.) ; nutrition and B vitamins (June 21, 10 a.m.) ; cortisone and A.C.T.H. (June 25, 10 a.m.) ; physiology of the vascular system (June 25,4 p.m.) ; tropical medicine (June 26, 4.30 p.m.) ; epidemiology (June $27,4.30$ p.m.). Tickets can be obtained from the joint secretary of symposia at B.M.A. House, Tavistock Square, London, W.C.1, and application forms from the May 4 issue of the British Medical Journal should be used, if possible.

THE Historical Association will be holding its seventh vacation school for revision courses in history in Thwaite Hall (University College of Hull), Cottingham, East Yorks, during August 2-13. The school is for graduate history teachers and others who are interested, and each member will choose to study within one of seven seminars, there being a tutor and about twelve students in each seminar. One of the seminars is on the "History of Science in the Seventeenth and Eighteenth Centuries", with A. R. Hall, assistant lecturer in the history of science in the University of Cambridge, as tutor. The fee for the course, exclusive of accommodation, is $£ 5$ (£4 10s. to members of the Association). Registration forms, to be completed by May 31, and further details can be obtained from the director of the school, F. W. Brooks, 14 Wellesley Avenue, Hull.

Astir is preparing a central index of translations, which will include scientific papers, reports and published articles appearing in foreign journals, and which when complete is intended to provide a guide to all translations held in Great Britain and the Commonwealth. A limited number of translations has already been indexed, and inquiries concerning them are dealt with free of charge. To ensure that the index will be complete the co-operation of persons and organizations holding translations is requested. All communications should be addressed to Aslib, 4 Palace Gate, London, W.8. 